\title{
A COMPARISON OF THE CREATININE AND UREA CLEAR- ANCE TESTS OF KIDNEY FUNCTION
}

\author{
By J. M. HAYMAN, JR., J. A. HALSTED AND L. E. SEYLER \\ (From the H. K. Cushing Laboratory of Experimental Medicine in the Department \\ of Medicine of Western Reserve University, and the Medical \\ Service of Lakeside Hospital, Cleveland)
}

(Received for publication May 1, 1933)

The urea clearance test developed by Möller, McIntosh and Van Slyke (1) has one disadvantage, namely, that maximum and standard clearances are only comparable by reference to the average normal value for each or by multiplying the standard clearance by a constant. In addition the standard clearance, involving the square root of the urine volume, is difficult to interpret. The creatinine clearance test, developed by Rehberg (2), is not subject to these objections, since the excretion of creatinine is independent of urine volume. It therefore seemed worth while to compare the creatinine and urea clearances as a test of renal function, to determine if there was sufficient practical advantage in the creatinine test to compensate for the added technical difficulties.

Rehberg presented evidence that led him to believe that the creatinine clearance represented the volume of glomerular filtrate, and on this assumption calculated the quantities of urea and chloride reabsorbed. Rehberg's conception has been accepted by Wyschegorodzewa (3), Bergwall $(4)$, and others $(5,6)$; questioned by Cope $(7)$ and Ekehorn $(8)$; and denied by Shannon, Jolliffe and Smith (9). The evidence at present available does not, in our opinion, justify unreservedly accepting the creatinine clearance as equal to the volume of glomerular. filtrate, and while this lessens the value of the test as a tool in the study of renal physiology, it need not detract from its usefulness as a practical test of kidney function.

\section{METHODS}

Hospital patients were kept in bed for the period of the test. Dispensary patients and normal subjects were allowed to sit in a chair or engage in light laboratory work. Some tests were made after fourteen hours' fast, the majority after a light breakfast which MacKay (10) found had no effect on the urea clearance. Three to five grams of creatinine were given by mouth an hour to one and one-half hours before the beginning of the test. At the beginning of the test, the bladder was emptied as completely as possible and a sample of venous blood obtained. Approximately an hour later, but timed to the nearest minute, the bladder 
was again emptied as completely as possible and a second sample of blood obtained. If there was any doubt whether the subject could empty the bladder, he was catheterized. All blood analyses were made on serum.

Urea nitrogen in urine and serum was estimated by the gasometric method of Van Slyke (11); in a few instances by Van Slyke and Cullen's (12) method. All analyses were made in duplicate. Creatinine in urine and serum was estimated by Rehberg's (13) modification of Folin's method, using a colorimeter with Bürker optical system.

The ingestion of three to five grams of creatinine increases the plasma concentration to 5 to $10 \mathrm{mgm}$. per cent. This decreases the effect of substances other than creatinine in plasma which give the Jaffe reaction, as well as making the estimation more certain. Since Behre and Benedict (14) and Gaebler (15) have doubted the existence of creatinine in normal blood, and since Gaebler could recover only a relatively small fraction of the creatinine added to blood, it was felt that the creatinine analyses had to be examined before any reliance could be placed on the calculation of creatinine clearance by the formula $U V / B=C$. By the method used in these experiments the average recovery of creatinine added to serum in amounts equivalent to 0.5 to $15.0 \mathrm{mgm}$. per $100 \mathrm{cc}$. was 93.5 per cent in 15 experiments, the extremes being 80 and 124 per cent. Table I shows

TABLE I

Comparison of creatinine clearances calculated from total chromogenic substances and from ingested creatinine only

\begin{tabular}{|c|c|c|c|c|c|c|}
\hline \multirow{2}{*}{ Name } & \multicolumn{2}{|c|}{ Before ingestion } & \multicolumn{2}{|c|}{ After ingestion } & \multirow{2}{*}{\multicolumn{2}{|c|}{$\begin{array}{l}\text { Creatinine } \\
\text { clearance } \dagger\end{array}$}} \\
\hline & $\underset{\text { "creatinine" }}{\text { Serum }}$ & $\begin{array}{c}\text { Creatinine } \\
\text { excreted }\end{array}$ & $\begin{array}{c}\text { Average serum } \\
\text { creatinine }\end{array}$ & $\begin{array}{c}\text { Creatinine } \\
\text { excreted }\end{array}$ & & \\
\hline & mgm. per cent & $\underset{\text { minute }}{\text { mgm. per }}$ & $\underset{\text { cent }}{\operatorname{mgm.} \text { per }}$ & $\underset{\text { minute }}{\operatorname{mgm.} \text { per }}$ & $\boldsymbol{A}$ & $\boldsymbol{B}$ \\
\hline J. M. H. .. & $1.27^{*}$ & $1.42^{*}$ & $\begin{array}{r}9.63 \\
8.31\end{array}$ & $\begin{array}{l}12.72 \\
10.30\end{array}$ & $\begin{array}{l}132 \\
124\end{array}$ & $\begin{array}{l}134 \\
126\end{array}$ \\
\hline White.......... & 0.95 & 1.37 & $\begin{array}{r}12.22 \\
6.16\end{array}$ & $\begin{array}{l}12.50 \\
10.05\end{array}$ & 163 & 166 \\
\hline Wilson . . . . . . . . & 1.08 & 1.59 & 8.28 & 8.08 & 106 & 100 \\
\hline Letcher . . . . . . . & 1.01 & .89 & 9.20 & 11.05 & 120 & 124 \\
\hline
\end{tabular}

* Average of 4 determinations.

$+A$-clearance calculated from total chromogenic substance in serum and urine.

$B$-clearance calculated from ingested creatinine only, subtracting value of chromogenic substances normally present in serum and average rate of excretion of creatinine before ingestion.

that there is no difference in the clearance calculated on total chromogenic substances in serum and urine after ingestion of creatinine and in the clearance calculated on ingested creatinine only. Gaebler and Keltch (16) have shown that all the chromogenic material adsorbed on Lloyd's reagent 
and released again is indistinguishable from creatinine. Therefore, a clearance calculated on the material released from Lloyd's reagent should be higher than that calculated on total chromogenic substances when no creatinine has been fed, since other substances account for a considerable fraction of the value obtained for "creatinine" in normal serum. After ingestion of creatinine, the clearances calculated before and after the use of Lloyd's reagent should show much less difference. Table II shows that

TABLE II

Comparison of creatinine clearances calculated from total chromogenic substances and from material released from Lloyd's reagent with and without ingestion of creatinine

\begin{tabular}{|c|c|c|c|c|c|c|c|c|}
\hline \multirow{2}{*}{\multicolumn{2}{|c|}{$\begin{array}{l}\text { Experimental } \\
\text { number and } \\
\text { condition }\end{array}$}} & \multirow{2}{*}{$\begin{array}{l}\text { Urine } \\
\text { volume }\end{array}$} & \multicolumn{3}{|c|}{ Total "creatinine" } & \multicolumn{3}{|c|}{ Released from Lloyd's } \\
\hline & & & Serum & Urine & Clearance & Serum & Urine & Clearance \\
\hline \multirow{4}{*}{\multicolumn{2}{|c|}{$\begin{array}{l}\text { No } \\
\text { 3. } \\
\text { creatinine } \\
\text { ingested }\end{array}$}} & $\begin{array}{l}c c \text { per } \\
\text { minute }\end{array}$ & $\underset{\text { cent }}{\operatorname{mgm.} \text { per }}$ & $\underset{\text { per cent }}{\operatorname{mgm} .}$ & $\begin{array}{l}c c \text {. per } \\
\text { minute }\end{array}$ & $\underset{\text { cent }}{\operatorname{mgm} \text {. per }}$ & $\begin{array}{l}\text { mgm. } \\
\text { per cent }\end{array}$ & $\begin{array}{l}\text { cc. per } \\
\text { minute }\end{array}$ \\
\hline & & 6.84 & 1.01 & 131 & 89 & .84 & 136 & 111 \\
\hline & & 7.07 & 1.30 & 20 & 109 & .96 & 18 & 133 \\
\hline & & 7.75 & 1.32 & 18 & 106 & .87 & 14 & 125 \\
\hline \multirow{3}{*}{$\begin{array}{l}4 . \\
5 . \\
6 .\end{array}$} & Creatinine & 7.72 & 9.63 & 165 & 132 & 9.03 & 159 & 136 \\
\hline & ingested & 1.95 & 12.22 & 642 & 102 & 10.99 & 600 & 106 \\
\hline & & 9.35 & 6.16 & 108 & 164 & 6.02 & 101 & 157 \\
\hline
\end{tabular}

this is the case. These experiments led us to believe that with serum concentrations of creatinine above $5 \mathrm{mgm}$. per cent, the creatinine clearance could be calculated on total chromogenic substance present in serum and urine without significant error.

In order to estimate the range of creatinine clearance in normal individuals under conditions of hospital and office practice, 59 clearances on 59 apparently healthy individuals were tabulated. In 45 of these, only a single test was made. In 14, from 2 to 21 clearances were determined. For these, the first clearance determined was tabulated. The range in these 59 observations was from 87 to $232 \mathrm{cc}$. per minute, the mean $144 \mathrm{cc}$. per minute with a standard deviation of $36 \mathrm{cc}$. When repeated tests are made of the same individual, there is a similar wide dispersion, but the limits for all clearances which we have obtained from normal individuals are only slightly wider. Nor apparently does any normal individual tend to have a constantly high or low clearance.

For this reason, it seemed proper to include all our observations (130) of normal individuals where no recognized unusual factor, such as administration of a drug or exercise, was present to show the normal chance distribution of clearances. If this be done, the range is from 70 to $238 \mathrm{cc}$. per minute, the mean $148 \mathrm{cc}$. per minute with a standard deviation of $34 \mathrm{cc}$. A frequency polygram of these observations shows a decided skewness, but not sufficient to make unreasonable the belief that the chances of a single 
clearance of a normal adult falling between 80 and 216 are about $24: 1$. (Fig. 1).

McIntosh, Möller and Van Slyke (17) found that more constant normal values for urea clearance were obtained if a correction was made for surface area. This seems reasonable for Taylor, Drury and Addis (18) were able to show that kidney weights in rabbits varied in proportion to surface area rather than to body weight. To avoid an error greater than \pm 5 per cent in using the formula $U V / B=C$, body size can be neglected only in adults between 164 and $176 \mathrm{~cm}$. in height. We have corrected the creatinine clearance values by the factor $(1.75 / A)$ where $A$ is surface area

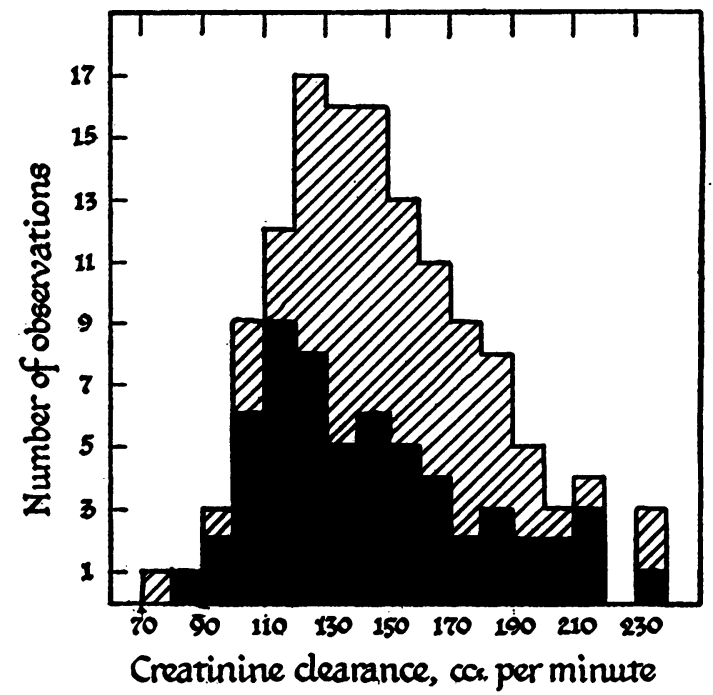

Fig. 1. Frequency Polygram of 130 Creatinine Clearance Values on 59 Normal Adults

The solid area includes only the first observation made on each person.

in square meters. This amounted to more than 10 per cent in 5 instances. The average of the corrected clearances is $145 \pm 34 \mathrm{cc}$. per minute, and the dispersion practically the same as for the uncorrected values. Since other unknown factors produce a much greater variation in clearances done on the same individual at different times than the amount of the correction for surface area, we feel that this correction is unnecessary in the case of adults except possibly for those of extreme heights. We have not applied the correction in the patients studied.

From our experience with normal subjects and patients suffering from various diseases, we have come to believe that creatinine clearances below $60 \mathrm{cc}$. per minute (41 per cent of average normal) are definitely abnormal, and those between 60 and $80 \mathrm{cc}$. per minute (41 to 54 per cent average normal) doubtful but significant if a repeated test is in the same range. 
This is a lower normal limit than Holten and Rehberg (19) use. They found the clearance always above $100 \mathrm{cc}$. per minute in normal individuals when tested between 10 and 11 a.m. But in 89 clearances reported by Rehberg of himself where experimental conditions were more varied regarding posture and fluid intake, the clearance was 9 times between 80 and $100 \mathrm{cc}$. per minute, and twice between 60 and $80 \mathrm{cc}$. per minute, so that a patient cannot be said to have diminished renal function on the basis of a single creatinine clearance test between 60 and $100 \mathrm{cc}$. per minute.

The maximum urea clearance in 56 observations of 25 normal individuals ranged from 38 to $112 \mathrm{cc}$. per minute, with an average of $74.68 \mathrm{cc}$. per minute, and a standard deviation of 17.57 cc., identical with the average of $75 \mathrm{cc}$. per minute found by Möller, McIntosh and Van Slyke. The range in our subjects is somewhat greater than the extremes of $\mathbf{5 2 . 2}$ and $103.8 \mathrm{cc}$. per minute which they found. The mean standard urea clearance in 39 observations of 26 persons was $51 \mathrm{cc}$. per minute with a standard deviation of $10.11 \mathrm{cc}$. The range was from 30 to $67 \mathrm{cc}$. per minute. This is the same range found by Möller, McIntosh and Van Slyke (28.3 to $69.3 \mathrm{cc}$. per minute) while the mean is but slightly lower. Thus in the case of normal individuals creatinine and urea clearances have about the same degree of dispersion. The creatinine clearance is always numerically greater than the maximum urea clearance, although when the standard urea clearance is calculated using the square root of urine volume, the numerical value may be greater for urea than for creatinine clearance. In estimating reduction of kidney function we have used $148 \mathrm{cc}$. per minute as the average normal creatinine clearance, and $75 \mathrm{cc}$. and $54 \mathrm{cc}$. per minute as the average normal maximum and standard urea clearances.

A comparison of creatinine and urea clearances has been made 116 times on 93 patients with Bright's disease and certain other conditions (Tables III, IV and V). We have followed Addis's classification (20) of Bright's disease but have used the term acute instead of initial hemorrhagic Bright's disease. Patients with degenerative Bright's disease, of whom relatively few were examined, have been grouped with the miscellaneous cases in Table V. We have not had the opportunity of examining any patient in whom the diagnosis of "cryptic" degenerative Bright's disease (pure lipoid nephrosis) seemed proper. Cases 107-624 and 151-532 presented a typical picture at the time of some examinations, but had had hematuria some time previously. Both clearance tests frequently show marked reduction in kidney function before there is any elevation of blood urea nitrogen, decrease in two hour phenolsulphonphthalein output, or fixation of specific gravity. This was shown for the urea clearance by Van Slyke and his associates (21) and for creatinine by Holten and Rehberg (19). We have not found the decrease more constant or more marked in one test than the other. Just as in normal persons, the creatinine clearance is always numerically greater than the maximum urea clearance; the 


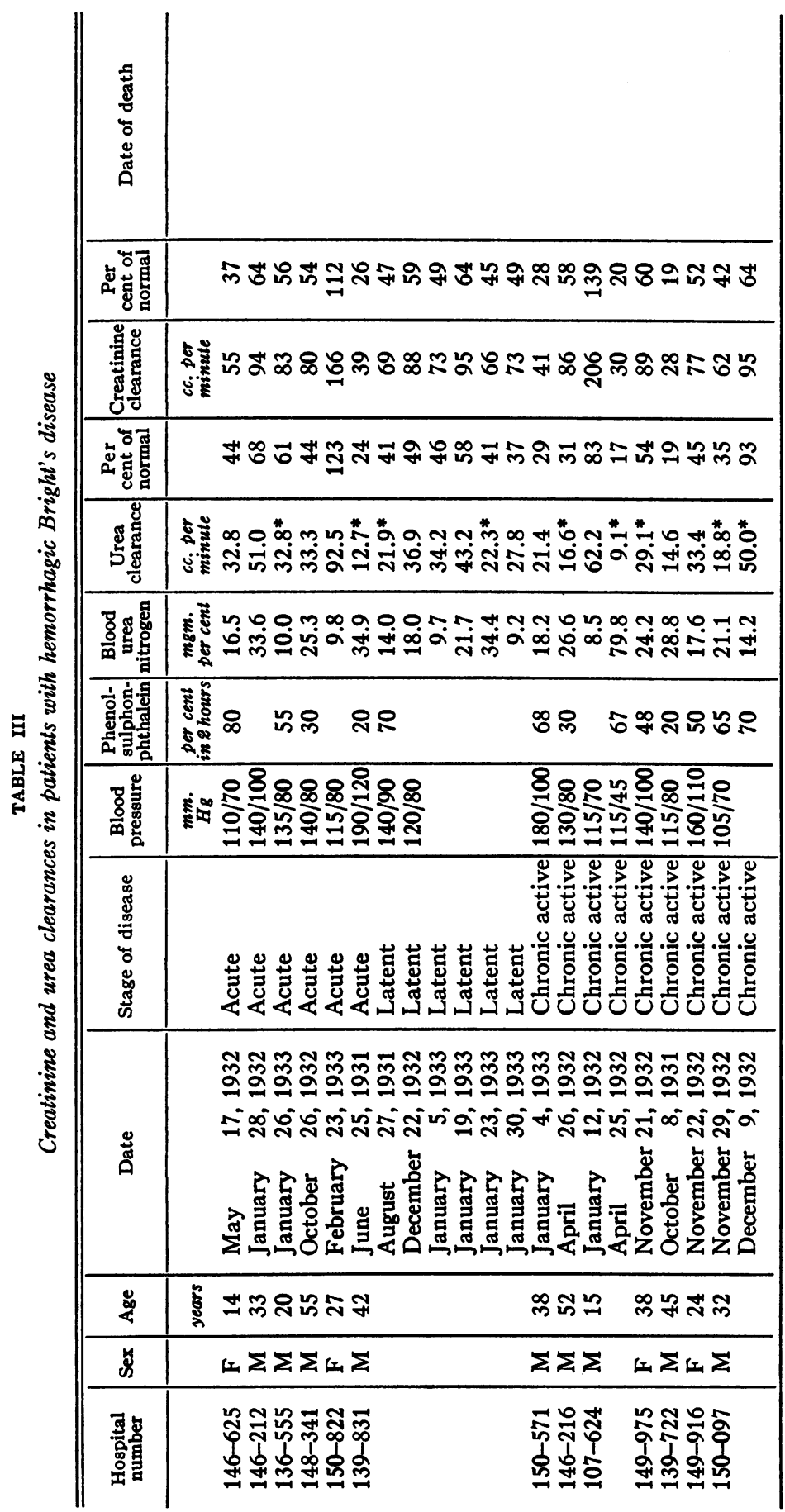




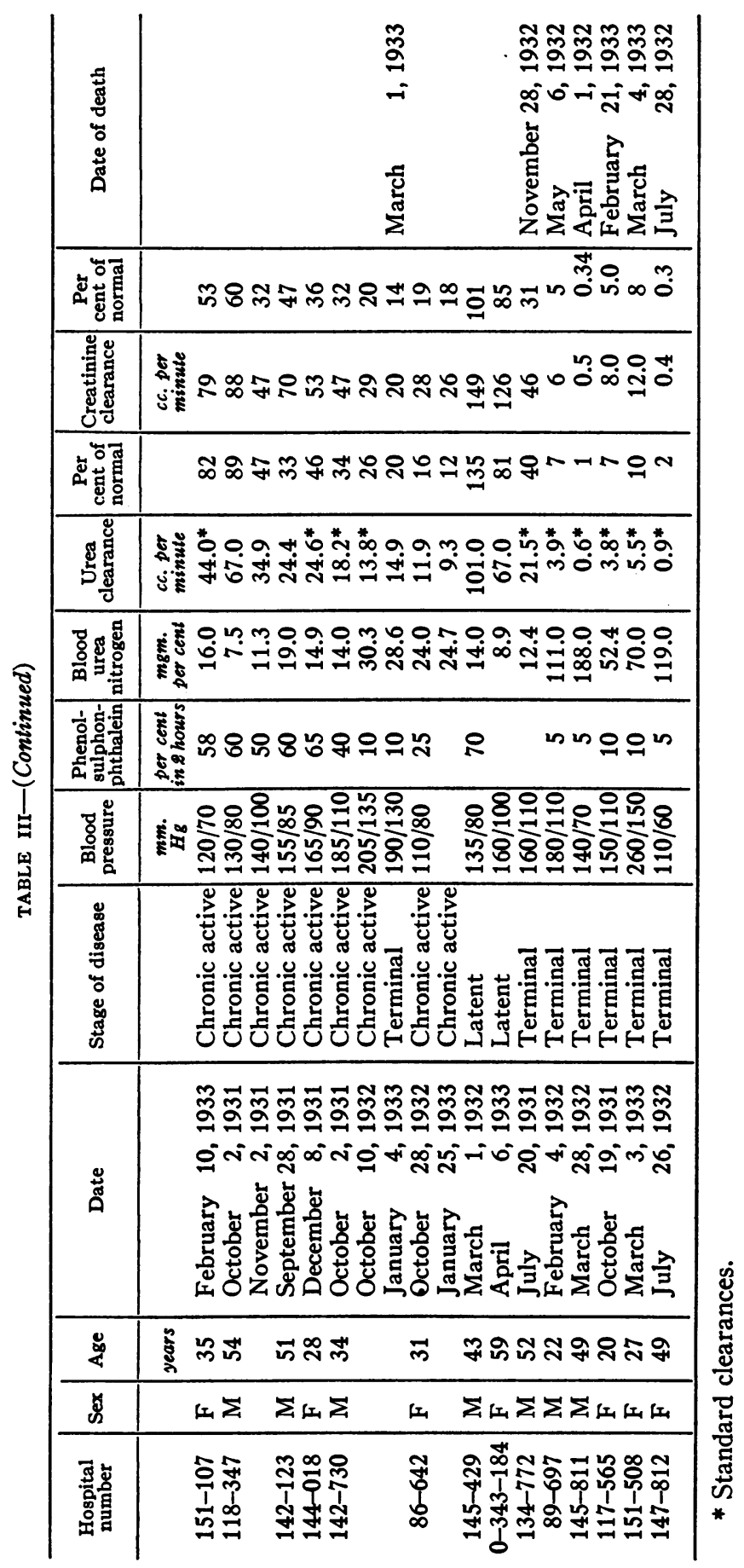




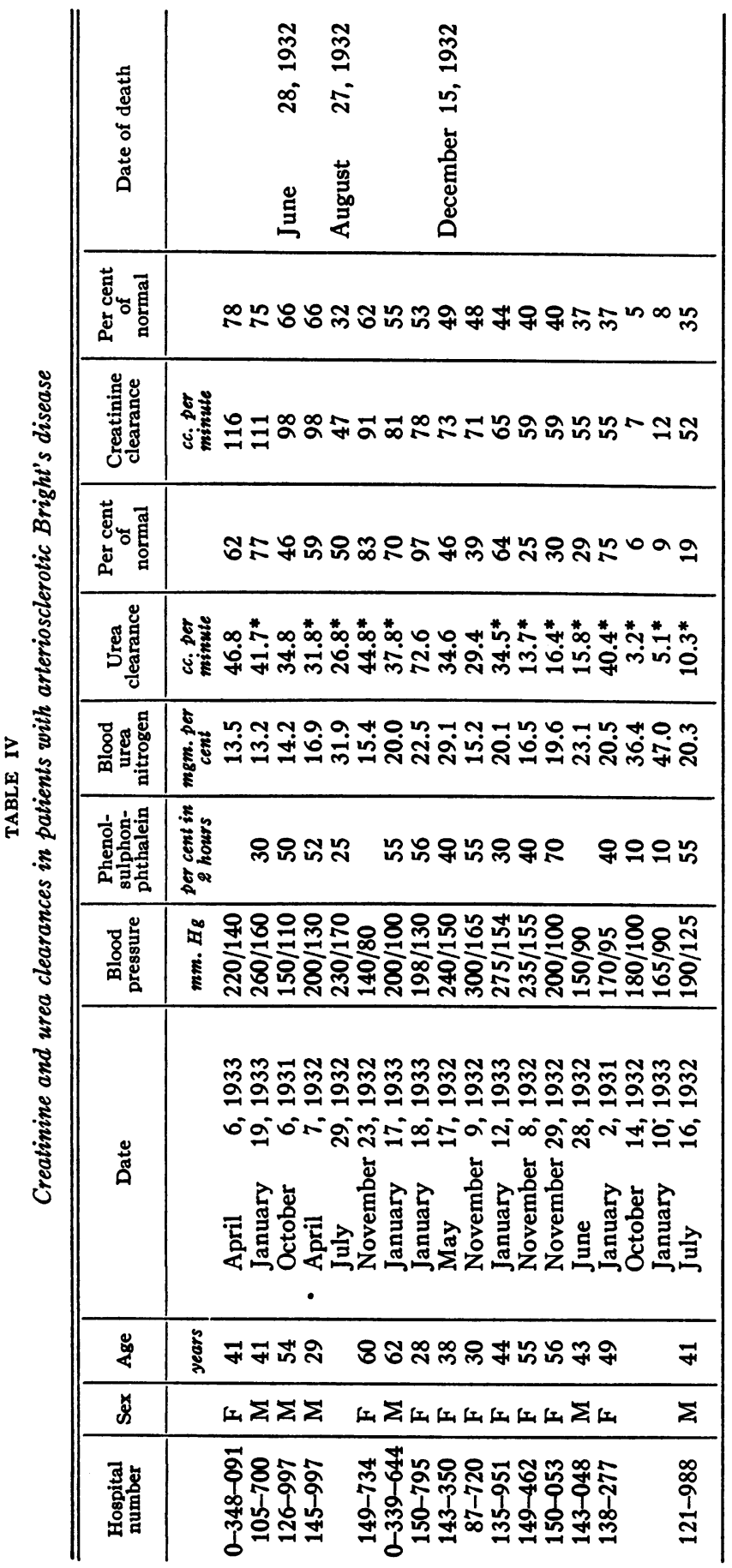


J. M. hAYMAN, JR., J. A. HALSTED AND L. E. SEYler

\begin{tabular}{|c|c|c|c|}
\hline 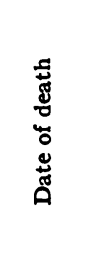 & 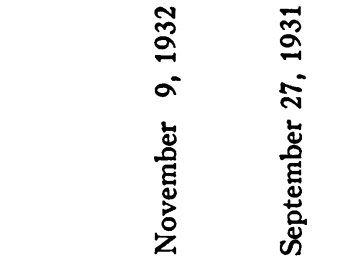 & 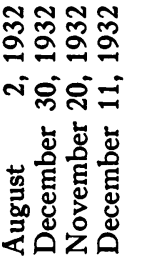 & 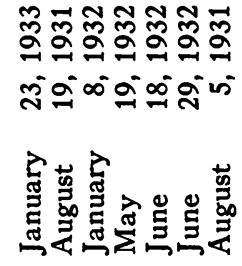 \\
\hline 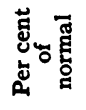 & \multicolumn{3}{|c|}{ 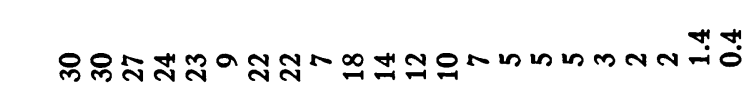 } \\
\hline 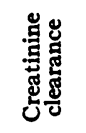 & \multicolumn{3}{|c|}{ 洁 } \\
\hline 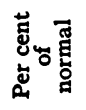 & \multicolumn{3}{|c|}{ 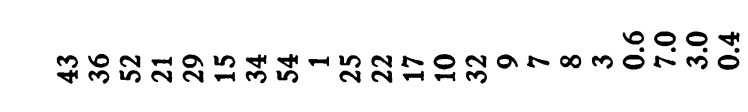 } \\
\hline 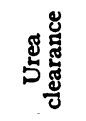 & \multicolumn{3}{|c|}{ 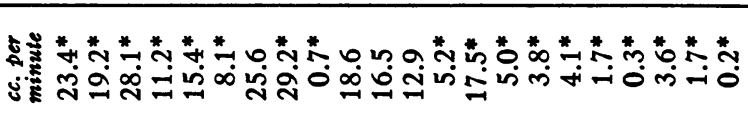 } \\
\hline 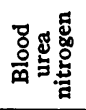 & \multicolumn{3}{|c|}{ ڤ్ } \\
\hline 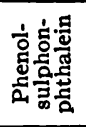 & \multicolumn{3}{|c|}{ 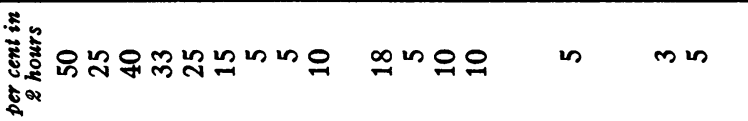 } \\
\hline 醇 & 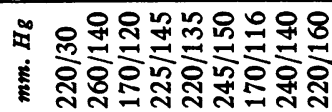 & \multicolumn{2}{|c|}{ 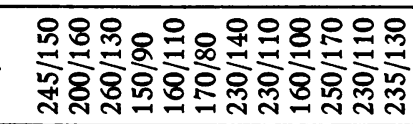 } \\
\hline ڤั & \multicolumn{3}{|c|}{ 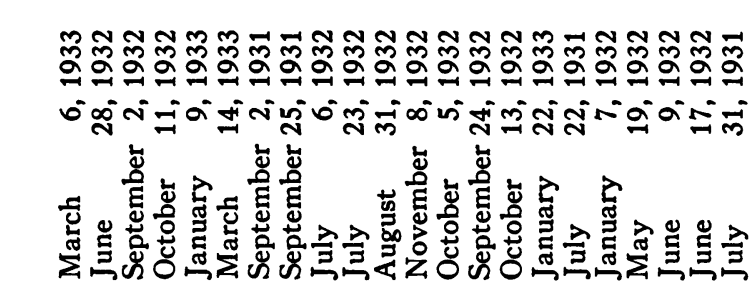 } \\
\hline 品 & 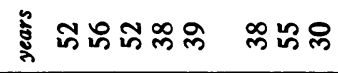 & 市ホ点 & 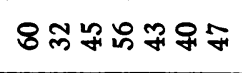 \\
\hline $\mathscr{y}$ & $\sum \sum \sum 心 \Sigma$ 山沙 & $\omega \sum \sum \omega$ & 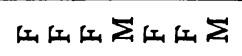 \\
\hline 䮦䓂 & 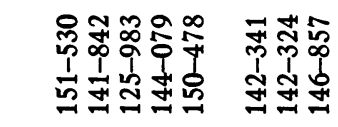 & 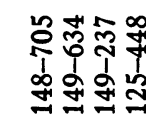 & 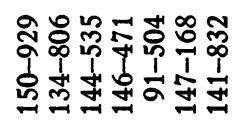 \\
\hline
\end{tabular}




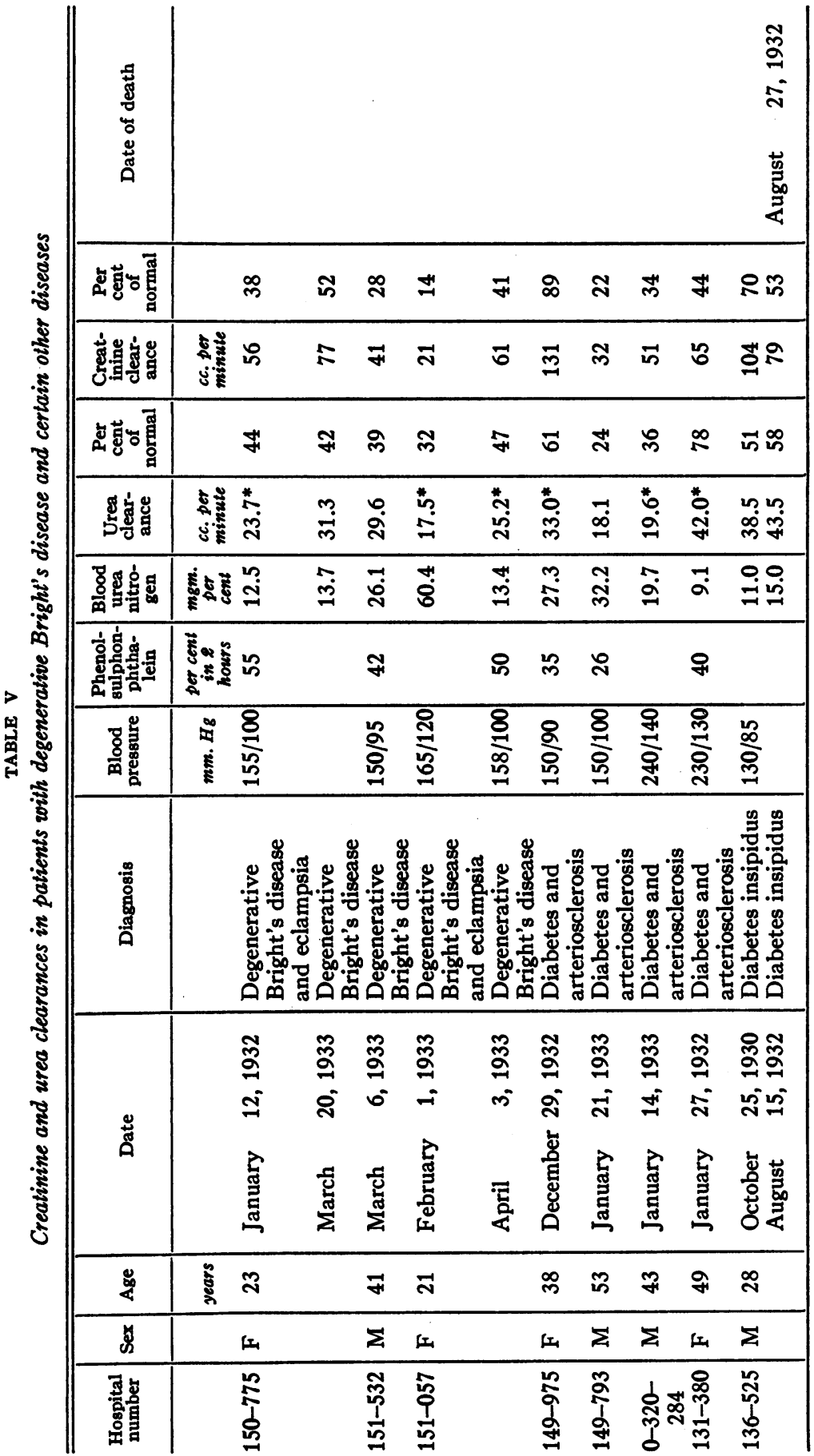


J. M. HAYMAN, JR., J. A. HALSTED AND L. E. SEYLER

\begin{tabular}{|c|c|c|c|c|c|c|c|c|}
\hline 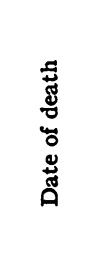 & & \multicolumn{3}{|c|}{ 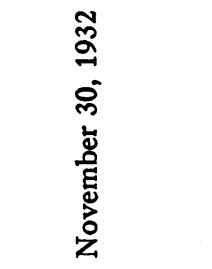 } & $\begin{array}{l}\tilde{N} \\
\text { a } \\
\bar{N}\end{array}$ & $\begin{array}{l}\text { ã } \\
\frac{a}{a} \\
\sum_{i}^{\pi}\end{array}$ & 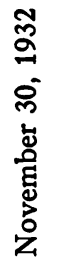 & 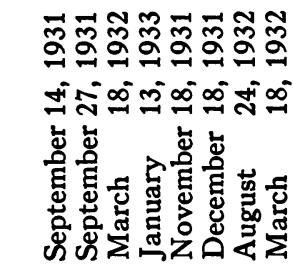 \\
\hline 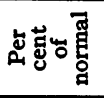 & & ஓ & ్ㅛ & 요 & 9 & นก & $\exists$ & 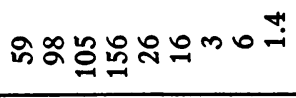 \\
\hline 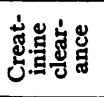 & S: & 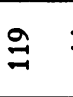 & $\mathbb{H}$ & $\mathbb{N}$ & $\stackrel{\infty}{\sim}$ & $\bar{\infty}$ & 유 & 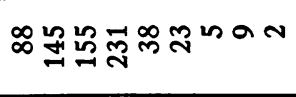 \\
\hline 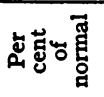 & & $\hat{m}$ & ส & बे & $\hat{N}$ & in & 8 & 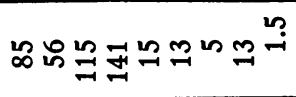 \\
\hline 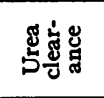 & : & ㅇ.. & $\stackrel{*}{=}$ & $\stackrel{*}{\stackrel{-}{*}}$ & $\stackrel{*}{\sharp}$ & $\stackrel{*}{*}$ & 萑 & 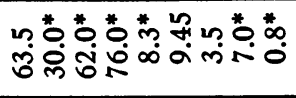 \\
\hline 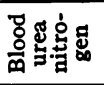 & Eह & $\bar{\infty}$ & मัं & $\begin{array}{l}0 \\
\stackrel{i}{\rightarrow}\end{array}$ & ?ִ & $\stackrel{9}{0}$ & $\stackrel{0}{\circ}$ & 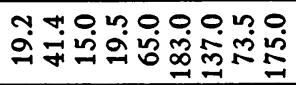 \\
\hline 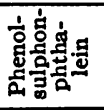 & 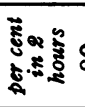 & $\varnothing$ & & & & 응 & & 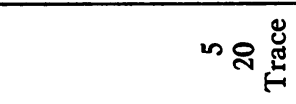 \\
\hline 总 & 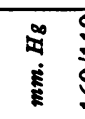 & $\underset{0}{\stackrel{0}{0}}$ & 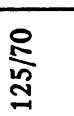 & $\stackrel{?}{\circ}$ & $\frac{8}{9}$ & 啹 & $\frac{8}{8}$ & 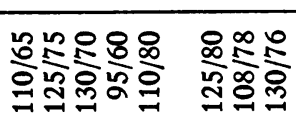 \\
\hline 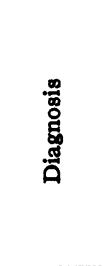 & & 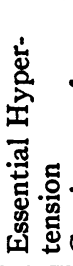 & 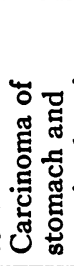 & $\begin{array}{l}2 \\
0\end{array}$ & 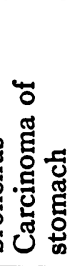 & 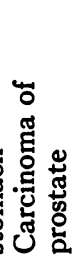 & 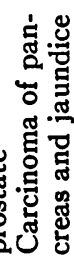 & 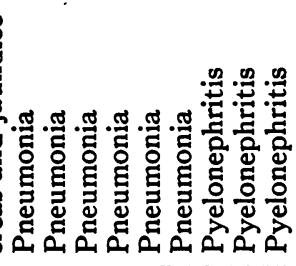 \\
\hline ڤัّ & & 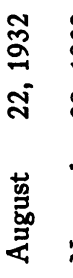 & 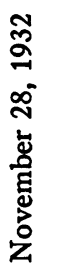 & 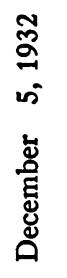 & $\begin{array}{l}\stackrel{2}{2} \\
\stackrel{-}{0} \\
\stackrel{\Xi}{\Xi}\end{array}$ & 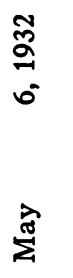 & 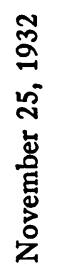 & 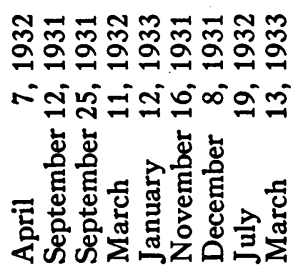 \\
\hline 品 & 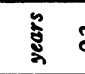 & $\ddot{v}$ & $\hat{0}$ & ガ & 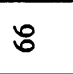 & $\stackrel{n}{2}$ & กิ & 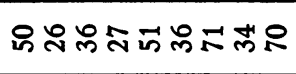 \\
\hline 4 & & $\Sigma$ & a & $\Sigma$ & a & $\Sigma$ & I & $\sum \sum \sum \sum \Sigma \Sigma \Sigma \Sigma 山 4$ \\
\hline 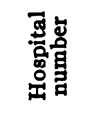 & & 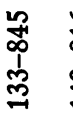 & $\begin{array}{l}0 \\
0 \\
0 \\
\alpha \\
q \\
-1\end{array}$ & 柋 & ஷ্ণ & 总 & 合 & 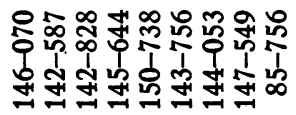 \\
\hline
\end{tabular}




\begin{tabular}{|c|c|c|c|c|c|c|c|}
\hline 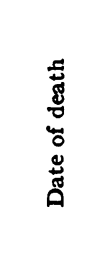 & 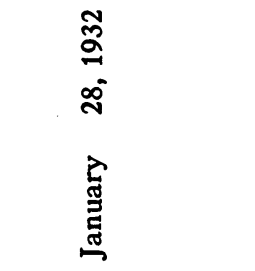 & & & & & & 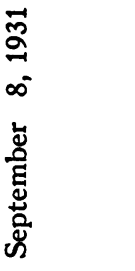 \\
\hline 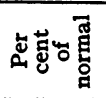 & ‡ & q & $\boxplus$ & 요 & : & $\stackrel{2}{\circ}$ & N \\
\hline 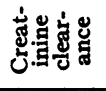 & 势第品 & $\stackrel{\circ}{\circ}$ & $\bar{\sim}$ & 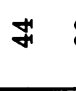 & on in & A & $m$ \\
\hline 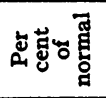 & $m$ 정ํํ요 & in & 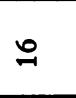 & 요 & $\infty$ & $\tilde{m}$ & in \\
\hline 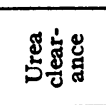 & 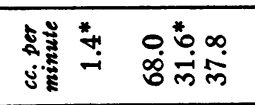 & $\stackrel{\circ}{\mathscr{H}}$ & $\vec{\Xi}$ & $\stackrel{m}{2}$ & 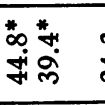 & $\stackrel{m}{i}$ & in \\
\hline 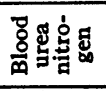 & 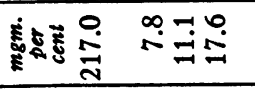 & $\stackrel{n}{0}$ & i⿱ & జ్లై & 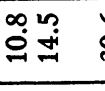 & ¿̊户 & $\stackrel{\infty}{\infty}$ \\
\hline 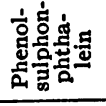 & 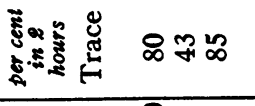 & & q & & 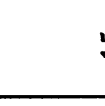 & $\rightarrow$ & 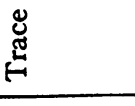 \\
\hline 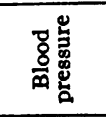 & 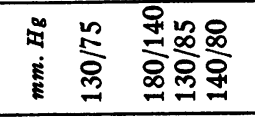 & & \& & & 总足 & $\frac{2}{8}$ & $\frac{8}{\frac{8}{2}}$ \\
\hline 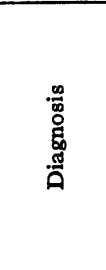 & 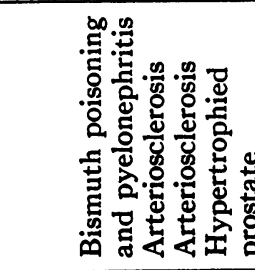 & 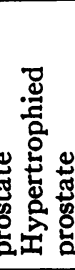 & 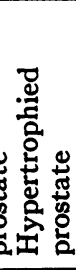 & 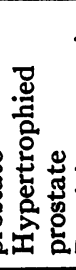 & 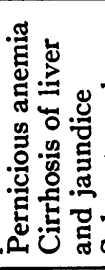 & 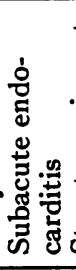 & 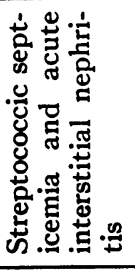 \\
\hline 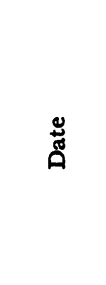 & 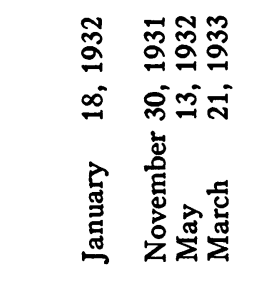 & 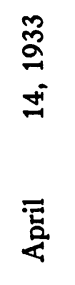 & 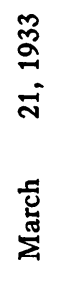 & $\begin{array}{l}\frac{m}{2} \\
\frac{m}{2} \\
\frac{2}{4}\end{array}$ & 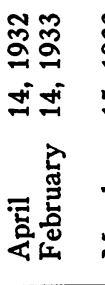 & 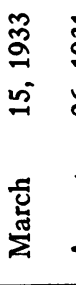 & 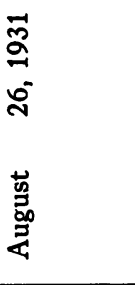 \\
\hline 遂 & 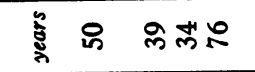 & & $\because$ & & iి & in & 9 \\
\hline 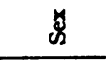 & $\Sigma 山 么 \Sigma$ & & $\Sigma$ & & $\sum_{1}$ & $\Sigma 1$ & 幽 \\
\hline 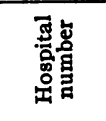 & 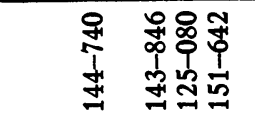 & & 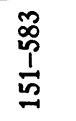 & & 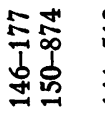 & $\frac{7}{1}$ & $\begin{array}{l}\vec{a} \\
0 \\
\dot{D} \\
\vec{y}\end{array}$ \\
\hline
\end{tabular}


standard urea clearance, however, may have a greater numerical value than the creatinine clearance determined at the same time, since the concentration ratio is multiplied by the square root of urine volume in the former and by the volume in the latter.

A direct comparison of the two clearance tests is shown in Figure 2 in which the results of each test are plotted as percentage of average normal.

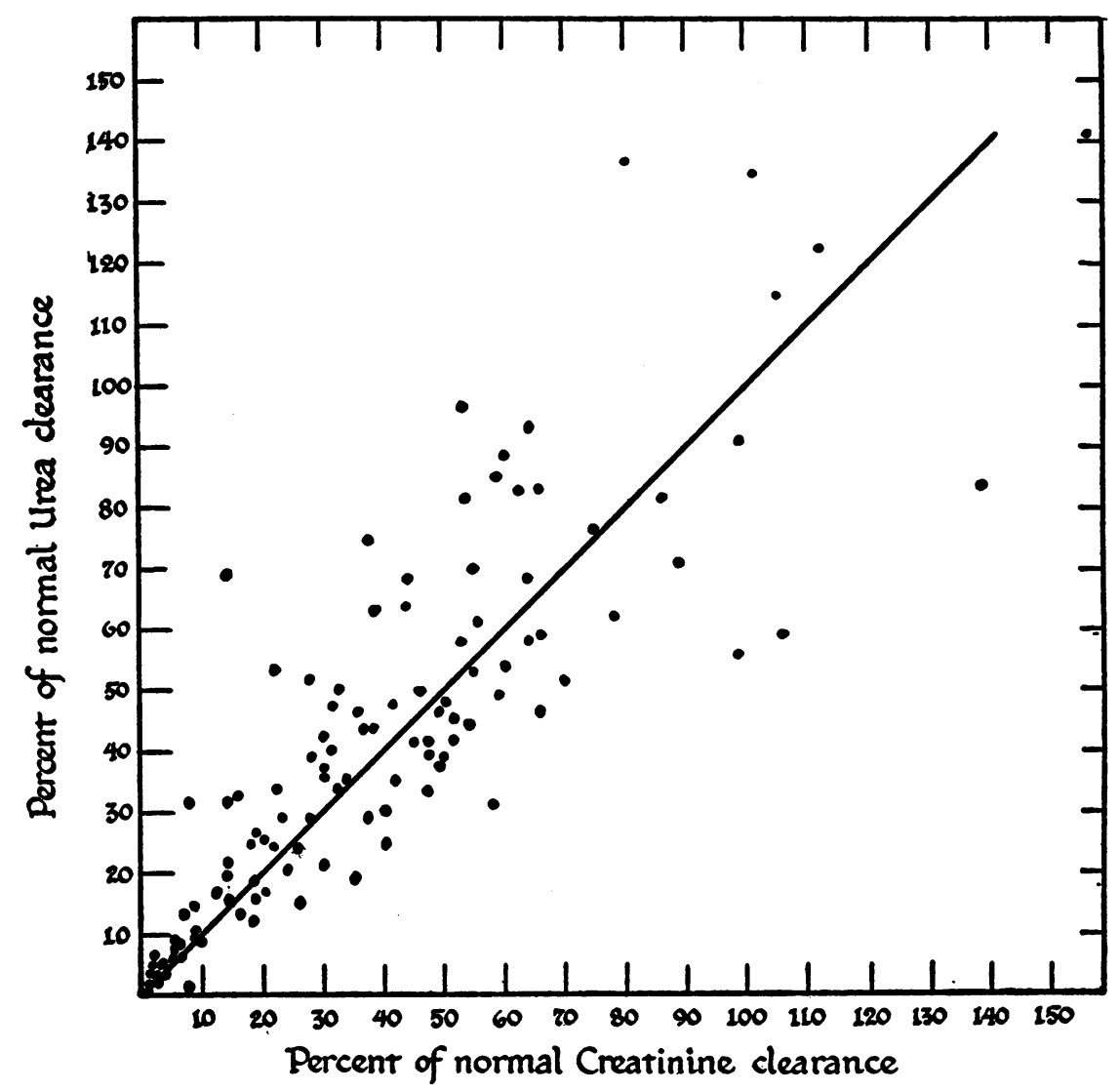

Fig. 2. Comparison of Creatinine and Urea Clearance Tests in Patients with Brights Disease and Certain Other Conditions

Points above the line indicate instances in which the urea clearance showed less reduction than creatinine; those below, instances in which the percentage reduction in urea clearance was greater. In patients with creatinine clearances below 10 per cent of average normal, there is not much difference in the degree of reduction of the two tests. In 82 creatinine clearances between 10 and 80 per cent of average normal, the urea clearance was reduced to a greater degree in 32 , while in 50 it was not reduced to the same extent. These differences are of questionable significance when the 
wide range of normal variation in both tests is remembered. The most that can be said in favor of the creatinine test is that it may indicate a greater decrease in function more frequently than the urea clearance, but not with enough regularity to make up for the greater technical difficulty of the test. Nor have we been able to find any group of patients or any pathological condition in which the results of one test are consistently different from those of the other.

Since the creatinine test is more laborious and expensive, involving the ingestion of creatinine and the analysis of two blood samples, we do not believe it has any advantage in the routine estimation of the degree of impairment of kidney function in the clinic. If it can be satisfactorily shown that the creatinine clearance does approximate the volume of glomerular filtrate, then a comparison of the two tests, run simultaneously, will permit a much more intimate analysis of the parts played by variations in the volume of filtrate and degree of back diffusion in health and disease (19).

\section{CONCLUSIONS}

The creatinine and urea clearance tests have been compared in normal persons and in patients with Bright's disease. The mean creatinine clearance in 130 observations of 59 normal subjects was 148 cc. per minute. The variability of the two tests from the mean normal was approximately the same in our hands.

In patients with Bright's disease the creatinine and urea clearance tests are generally equally reduced in relation to the average normal. We were unable to demonstrate any practical advantage in the creatinine test to compensate for its greater technical difficulty.

\section{BIBLIOGRAPHY}

1. Möller, E., McIntosh, J. F., and Van Slyke, D. D., J. Clin. Invest., 1928, vi, 427. Studies of Urea Excretion. II. Relationship Between Urine Volume and the Rate of Urea Excretion by Normal Adults.

2. Rehberg, P. B., Biochem. J., 1926, xx, 447. Studies on Kidney Function. I. The Rate of Filtration and Reabsorption in the Human Kidney.

3. Wyschegorodzewa, V. D., Ztschr. f. d. ges. exper. Med., 1931, lxxv, 72. Zur Bestimmung der Nierenfunktion auf Grund der modernen Filtrations-Reabsorptionstheorie der Harnabsonderung.

4. Bergwall, A., Klin. Wchnschr., 1932, xi, 554. Glomerulusfiltratmengenbestimmungen bei Nierenkranken.

5. Hemingway, A., J. Physiol., 1933, 1xxvii, 13P. The Rate of Glomerular Filtration in the Perfused Kidney.

6. Ellis, L. B., and Weiss, S., J. A. M. A., 1933, c, 875 . Renal Function in Arterial Hypertension.

7. Cope, C. L., Quart. J. Med., 1931, xxiv, 567. The Excretion of Creatinine by the Human Kidney in Health and in Nephritis.

8. Ekehorn, G., Acta med. Scandinav., 1931, Supplement xxxvi. On the Principles of Renal Function. 
9. Shannon, J. A., Jolliffe, N., and Smith, H. W., Am. J. Physiol., 1932, cii, 534. The Excretion of Urine in the Dog. VI. The Filtration and Secretion of Exogenous Creatinine.

10. MacKay, E. M., J. Clin. Invest., 1929, vi, 505. Studies of Urea Excretion. V. The Diurnal Variation of Urea Excretion in Normal Individuals and Patients with Bright's Disease.

11. Van Slyke, D. D., J. Biol. Chem., 1927, 1xxiii, 695. Determination of Urea by Gasometric Measurement of the Carbon Dioxide Formed by the Action of Urease.

12. Van Slyke, D. D., and Cullen, G. E., J. Biol. Chem., 1916, xxiv, 117. The Determination of Urea by the Urease Method.

13. Rehberg, P. B., Zentralbl. f. inn. Med., 1929, i, 367. Uber die Bestimmung der Menge des Glomerulusfiltrats mittels Kreatinin als Nierenfunktionsprüfung, nebst einigen Bemerkungen über die Theorien der Harnbereitung.

14. Behre, J. A., and Benedict, S. R., J. Biol. Chem., 1922, lii, 11. Studies in Creatine and Creatinine Metabolism. IV. On the Question of the Occurrence of Creatinine and Creatine in Blood.

15. Gaebler, O. H., J. Biol. Chem., 1930, lxxxix, 451. Further Studies of Blood Creatinine.

16. Gaebler, O. H., and Keltch, A. K., J. Biol. Chem., 1928, lxxvi, 337. On the Nature of Blood Creatinine.

17. McIntosh, J. F., Möller, E., and Van Slyke, D. D., J. Clin. Invest., 1928, vi, 467. Studies of Urea Excretion. III. The Influence of Body Size on Urea Output.

18. Taylor, F. B., Drury, D. R., and Addis, T., Am. J. Physiol., 1923, 1xv, 55. The Regulation of Renal Activity. VIII. The Relation Between the Rate of Urea Excretion and the Size of the Kidneys.

19. Holten, C., and Rehberg, P. B., Acta med. Scandinav., 1931, 1xxiv, 479. Studies on the Pathological Function of the Kidneys in Renal Disease, Especially Bright's Disease. I.

20. Addis, T., J. A. M. A., 1925, 1xxxv, 163. A Clinical Classification of Bright's Disease.

21. Van Slyke, D. D., McIntosh, J. F., Möller, E., Hannon, R. R., and Johnston, C., J. Clin. Invest., 1930, viii, 357. Studies of Urea Excretion. VI. Comparison of the Blood Urea Clearance with Certain Other Measures of Renal Function. 